DOI https://doi.org/10.18551/rjoas.2020-11.11

\title{
LEAD CONTENT ANALYSIS IN FISH AS EARLY WARNING SYSTEM FOR FOOD SAFETY IN RAWA BANGKAU WATERS OF SOUTH KALIMANTAN
}

\author{
Yasmi Zarina*, Arifin Pathul, Sofiani Dini, Purwanto Timothy Edward \\ Faculty of Fisheries, University of Lambung Mangkurat, South Kalimantan, Indonesia
}

Riyadi Putut Har

Faculty of Fisheries and Marine Sciences, University of Diponegoro, Central Java, Indonesia

*E-mail:zairina.yasmi3@gmail.com

\begin{abstract}
The ecosystem of Rawa Bapai waters is located in the western part of Hulu Sungai Selatan Regency. However, community living near upstream also caries out agricultural, plantations and household activities. The increase in the liquid waste cannot be separated from the community's habits/behaviour to dispose of all waste of a place for bathing and washing as well as serving as a lavatory (toilet), kitchen, bottles/containers of pesticides into the water because of easiness and the absence of facilities. Some of these activities cause pollution, one of which is heavy metal lead $(\mathrm{Pb})$. Heavy metal lead is one of the toxic pollutants that can cause death (lethal) and non-death (sublethal, such as disruption of growth, behaviour and morphological characteristics of various aquatic organisms. Moreover, fish exposed to the lead is consumed by humans as a food source of animal protein. The purpose of this study was to analyze the lead content in various fish in the waters of Rawa Bangkau Lake and to evaluate the level of bioaccumulation and bioconcentration of lead content in various fish in the waters of Rawa Bangkau Lake. This research provides output in the form of heavy metal lead bioconcentration data in various fish in Rawa Bangkau waters as information and an early warning system for fisheries utilization, especially consumption fish in food safety. The results of the study indicated that $77 \%$ of fish samples from various types and locations did not meet the SNI (Indonesian National Standard) quality standards for fresh fish and the European Union (EU) standards related to lead content. It was only $7 \%$ that fulfilled SNI, but it did not meet the European Union standards. Meanwhile, 16\% met SNI and European Union Standards. This matter shows that the fish in the waters of Rawa Bangkau is not safe to consume. It is necessary to immediately implement an integrated and comprehensive management of Rawa Bangkau area to make the waters remain clean and healthy.
\end{abstract}

\section{KEY WORDS}

$\mathrm{Pb}$, fish, early warning system, food safety.

The ecosystem of Rawa Bangkau waters is located in the western part of Hulu Sungai Selatan Regency. Rawa Bangkau waters have a wide area of inundation that varies throughout the year. In the rainy season, the puddle extends to flooded swamps, and in the dry season, the water is trapped in swamps and excavated areas or swamp pools (Chairuddin et al., 1999). The surrounding community utilizes Rawa Bangkau waters for fisheries, both capture fisheries and aquaculture.

Also, community living near upstream caries out agricultural, plantations and household activities. The increase in the liquid waste cannot be separated from the community's habits/behaviour to dispose of all waste of a place for bathing and washing as well as serving as a lavatory (toilet), kitchen, bottles/containers of pesticides into the water because of easiness and the absence of facilities. So far, people assume to dispose domestic liquid waste into water bodies because they think water can recycle liquid waste physically, chemically and biologically in the form of dissolving almost all types of substances/materials (Khiatuddin, 2003). The low level of people's welfare, employment, poverty and education 
level affects them to dispose of waste into the water. Some of these activities cause pollution, one of which is heavy metal lead $(\mathrm{Pb})$.

Heavy metal lead is one of the toxic pollutants that can cause lethal and sublethal such as disruption of growth, behaviour and morphological characteristics of various aquatic organisms (Effendi, 2003). If heavy metal lead enters the body organism of living things (fish), it will experience bioconcentration (Connel and Miller, 2006), bioaccumulation (Darmono, 2001) and biomagnification. According to Ivanciuc et al., (2006), the bioaccumulation of chemicals in waters is a vital criterion in evaluating the ecology and level of environmental pollution. Moreover, fish exposed to the lead is consumed by humans as a food source of animal protein.

Food is the most important basic human need, and its fulfillment is part of the human rights of every Indonesian. In Indonesia, the implementation of food as a basic need is clearly stated to provide diverse food and meets the requirements of safety, quality and nutrition for public consumption (Law No.18/2012 on Food Chapter II, article 4, point b). Therefore, food safety and quality is an important aspect and even can be said to be a fundamental prerequisite for food in Indonesia.

The mission of marine and fisheries development includes improving the nation's intelligence and health by increasing fish consumption (Dahuri, 2004). It is because fish is rich in nutrients such as protein (20\%) with complete essential amino acids, contains omega3 (DHA and EPA), contains various vitamins A, D, E, K and minerals $\mathrm{Fe}, \mathrm{Ca}, \mathrm{Mn}, \mathrm{Zn}$. which is good for metabolism and body health. Judging from the way of treatment of fishery production, handling of fresh products and traditional processing as well as a polluted environment provide the most significant contribution in post-harvest fisheries activities in Indonesia (Riyadi, 2008). The condition of fishery products with low quality and insufficient safety will result in difficulties in achieving the mission of marine and fisheries development in increasing public intelligence and health through fish consumption. The condition of fishery products with low quality and insecure safety as mentioned above will undoubtedly fail to achieve the mission of marine and fisheries development in increasing intelligence and public health through fish consumption because those two qualities will affect health and even result in death. Also, it is feared that the public's interest in consuming fish will decrease in line with the increasing knowledge and awareness of the consumer community about health by consuming only quality and safe food. Besides, legally, a product of low quality and indicated to be unsafe contradicts existing laws and regulations, namely: (1) Law on Food No.18 of 2012 and (2) Law No.8 of 1999 concerning Consumer Protection.

On the other hand, fish exposed to lead metal will be consumed by humans as a food source of animal protein. Heavy metal lead is one of the toxic pollutants that can cause lethal and sub-lethal, such as disruption of growth, behaviour and morphological characteristics of various aquatic organisms. Lead toxicity to humans, also called lead poisoning, can be acute or chronic. Acute can cause loss of appetite, headaches, hypertension, abdominal pain, impaired kidney function, fatigue, wakeful, arthritis, hallucinations and vertigo. It generally occurs in the workplace and in some manufacturing industries that use lead. Chronic lead exposure can produce mental retardation, congenital disabilities, psychosis, autism, allergies, dyslexia, weight loss, hyperactivity, paralysis, muscle weakness, brain damage, kidney damage, and even can lead to death.

The purpose of this study was to analyze the lead content in various fish in the waters of Rawa Bangkau Lake and to evaluate the level of bioaccumulation and bioconcentration of lead content in various fish in the waters of Rawa Bangkau Lake. This research provides benefits in the form of heavy metal lead bioconcentration data in various fish in Rawa Bangkau waters, South Kalimantan as information and an early warning system for fisheries utilization, especially consumption fish in food safety.

\section{MATERIALS AND METHODS OF RESEARCH}

This research was conducted for three months (July-September 2020) in Rawa Bangkau waters, Hulu Sungai Selatan Regency, South Kalimantan Province. The research 
schedule can be seen in Table 1. Sampling activities were carried out three times with an interval of two weeks. The sampling location was determined purposively, namely in two locations, the outlet area and the middle of the swamp waters. For more details, figure 2 below illustrates the exact research location.

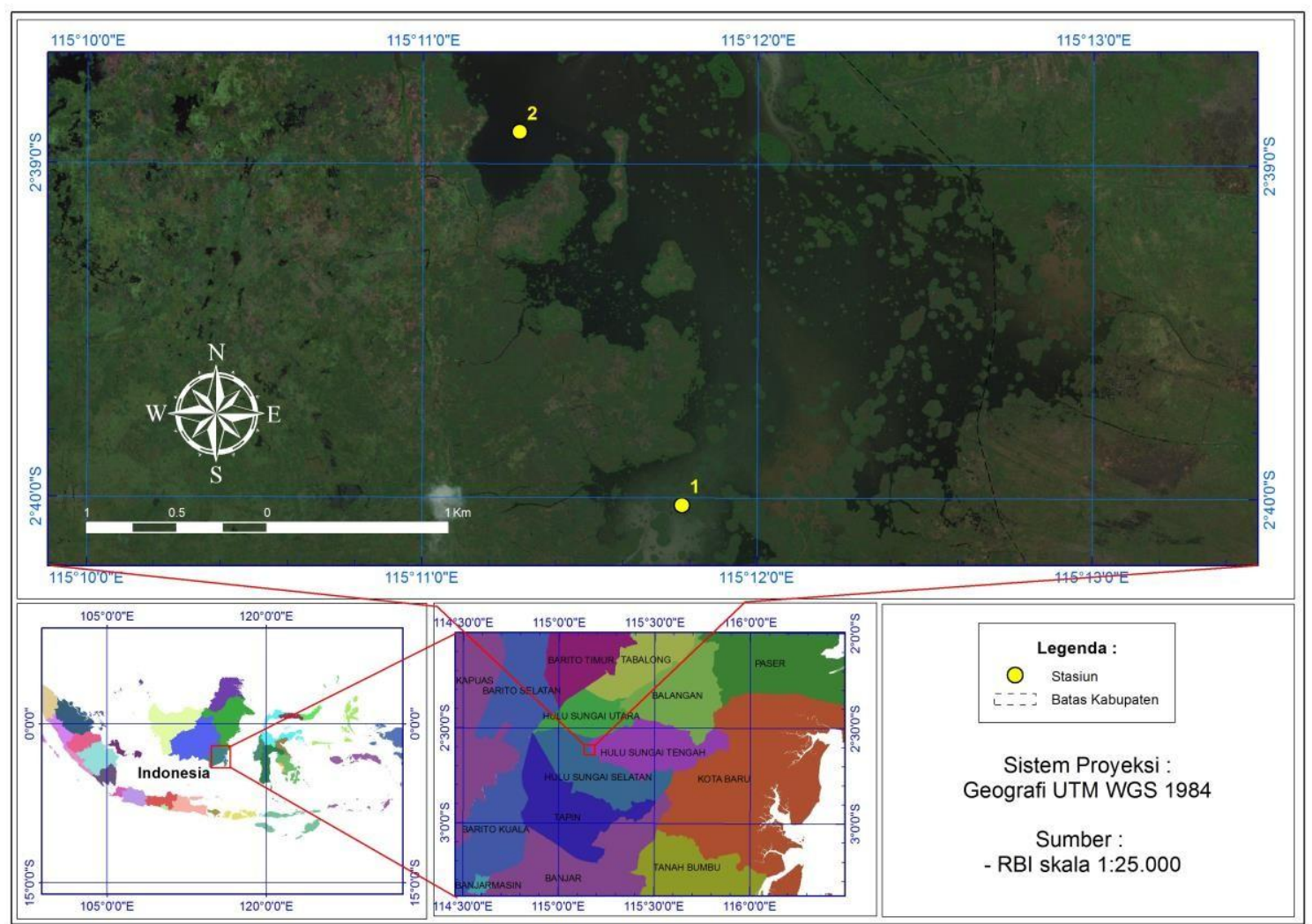

Figure 2 - Research Locations of Rawa Bangkau

The tools used to conduct thi research were fishing gear, fish identification book, camera, Atomic Absorption Spectrophotometer (AAS), GPS, Oven, Desiccator, Cooler Box, and Magnetic Stirrer.

The chemicals used in this study were lead mother liquor of $1000 \mathrm{ug} / \mathrm{ml}$, concentrated $\mathrm{HNO}_{3}(65 \%), \mathrm{HNO}_{3} 1.0 \mathrm{~N}, \mathrm{HNO}_{3} 10 \%$, concentrated $\mathrm{H}_{2} \mathrm{O}_{2}(30 \%)$, aquades, boiling stone, quantitative filter paper with sizes pore $8.0 \mathrm{um}, \mathrm{HCl} 1.0 \mathrm{~N}, \mathrm{NaOH} 0.1 \mathrm{~N}$, and glacial acetic acid. The biological materials used were several fish originating from the waters of Rawa Bangkau Lake; black fish such as papuyu fish (Anabas testudineus), Biawan (Helostoma temmincki), haruan (Channa striata) and singaringan (Mystus nigriceps), sepat siam fish (Trichogaster pectoralis) and the Cyprinidae family such as puyau (Osteochillus hassleti), siamis (Parachela oxygastroides), tahuman (Channa micropeltes) and sepatung (Pristolepis fasciatus).

The methods and stages of the research were as follows:

- Fish Sampling. Fish sampling was conducted using a gill net for a specific time following the specified location points;

- Preparation and Preservation of Fish Samples. Fish samples were then identified and stored in labelled plastic and cooled in a cooled box containing dry ice with a temperature of $4^{\circ} \mathrm{C}$. After that, the fish samples were taken to the laboratory for heavy metal testing.

Preparation of $100 \mathrm{ug} / \mathrm{ml} \mathrm{Pb}$ Standard Solution. $10 \mathrm{ml}$ out of $100 \mathrm{ug} / \mathrm{ml}$ lead mother liquor was put into a $100 \mathrm{ml}$ volumetric flask, then added nitrate solution, HNO3 $1.0 \mathrm{~N}$ until precisely up to the tera mark:

- Preparation of $10 \mathrm{ug} / \mathrm{ml} \mathrm{Pb}$ Standard Solution. $10 \mathrm{ml}$ out of $1000 \mathrm{ug} / \mathrm{ml}$ lead mother 
liquor was put into a $100 \mathrm{ml}$ volumetric flask, then added nitrate solution, HNO3 $1.0 \mathrm{~N}$ until precisely up to the tera mark. Preparation of working solutions with concentrations of $0.2 \mathrm{ug} / \mathrm{ml}, 0.4 \mathrm{ug} / \mathrm{ml}, 0.6 \mathrm{ug} / \mathrm{ml}, 0.8 \mathrm{ug} / \mathrm{ml}, 1.0 \mathrm{ug} / \mathrm{ml}, 3.0 \mathrm{ug} / \mathrm{ml}, 5.0$ $\mathrm{ug} / \mathrm{ml}$. $1.0 \mathrm{ml}, 2.0 \mathrm{ml}, 3.0 \mathrm{ml}, 4.0 \mathrm{ml}, 5.0 \mathrm{ml}, 15.0 \mathrm{ml}, 25.0 \mathrm{ml}$ of $\mathrm{Pb}$ standard solution was put into 6 (six) $50 \mathrm{ml}$ flasks, then added nitrate solution, $\mathrm{HNO}_{3} 1,0 \mathrm{~N}$ into each measuring flask until precisely up to the tera mark.

- Preparation of pH 3 Acid Fraction. This fraction was prepared by diluting $5.7 \mathrm{ml}$ of glacial acetate with aquades up to $1.0 \mathrm{~L}$.

- Preparation of pH 5 Acid Fraction. This fraction was prepared by diluting $5.7 \mathrm{ml}$ of glacial acetate and $64.3 \mathrm{ml}$ of $\mathrm{NaOH} 1.0 \mathrm{~N}$ and then diluted with aquades up to $1.0 \mathrm{~L}$.

- Measurement of Lead Content in Fish Samples. Fish samples were dried at an oven with a temperature of $105^{\circ} \mathrm{C}$ until got a constant temperature, digested using $10.0 \mathrm{ml}$ $\mathrm{HNO} 3$ and $2.0 \mathrm{H} 202$, then evaporated on an electric bath for $2-3$ hours at $60-70{ }^{\circ} \mathrm{C}$. The test sample filtrate was placed in a $25.0 \mathrm{ml}$ volumetric flask and added with $\mathrm{HNO}_{3}$ $1.0 \mathrm{~N}$ up to the tera mark. The sample filtrate was ready to be measured into the Atomic Absorption Spectrophotometer (AAS).

\section{RESULTS AND DISCUSSION}

Rawa Bangkau is located in Kandangan district, Hulu Sungai Selatan regency. This swamp is categorized as peatland with a total area of 17,000 ha, while the area for fisheries alone is 6 ha. Rawa Bangkau receives water from the main tributary. These tributaries are Pahalatan River, Nagara River, Bangkau River and Jarum River. All of these are tributaries of the Barito River. The area around this swamp is a fishing place for fishermen.

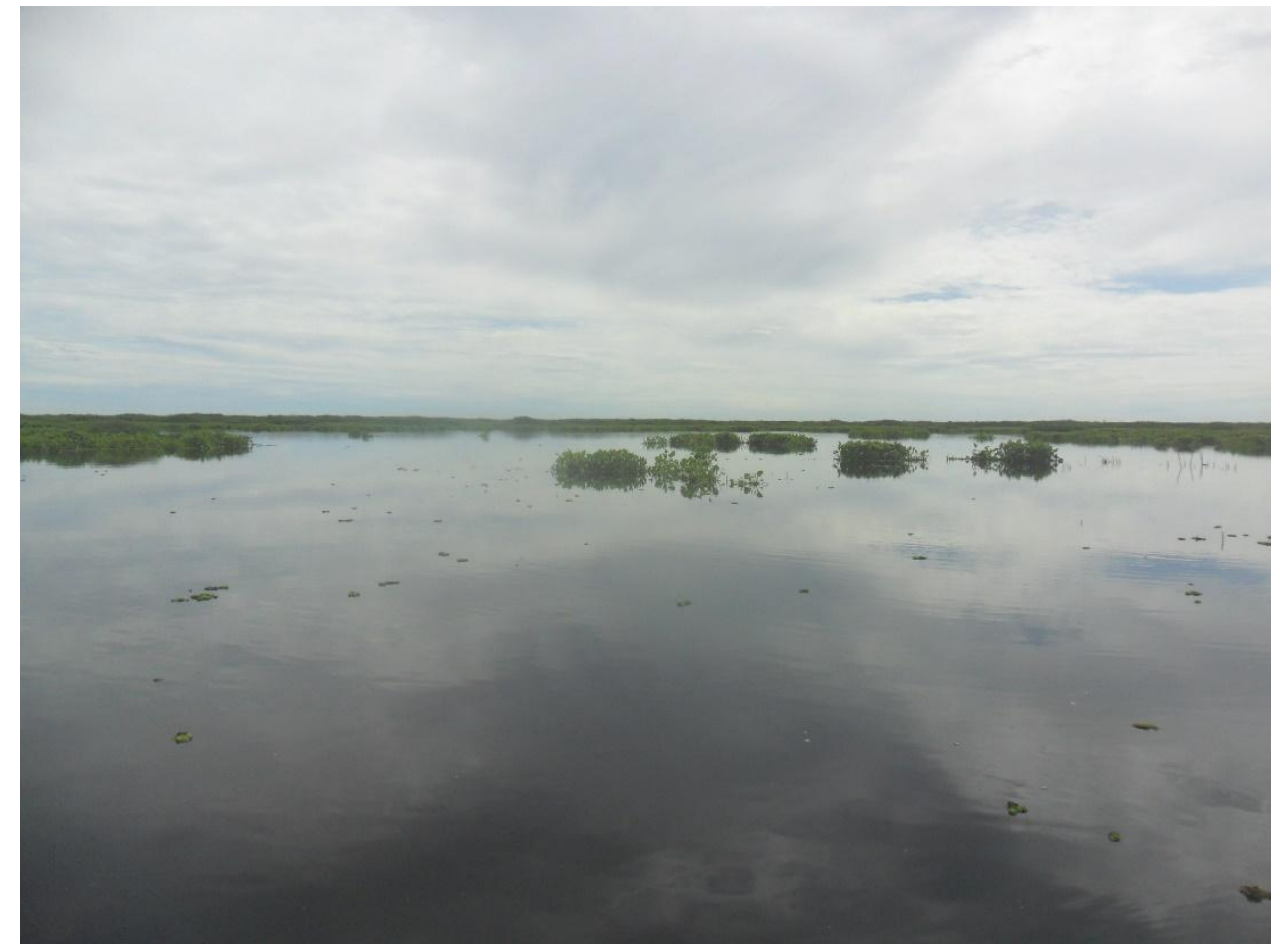

Figure 3 - The condition of Rawa Bangkau

Asyari (2006) states that there are 12 types of fish in Rawa Bangkau fishery, dominated by black fish such as papuyu (Anabas testudineus), Biawan (Helostoma temmincki), haruan (Channa striata) and singaringan (Mystus nigriceps).While the number of siam sepat fish (Trichogaster pectoralis) and the Cyprinidae family such as puyau (Osteochillus hassleti) and siamis (Parachela oxygastroides) were moderate, and the types of sepat rawa, tahuman (Channa micropeltes) and sepatung (Pristolepis fasciatus) were only 
a little. The types of fish in Rawa Bangkau fishery reserve are not much different from what Asyari et al.(2002) found in Teluk Rasau, dominated by black fish groups such as tembakang and sepat siam, while white fish are palau (Osteochilus hasselti) and damaian (Thynnichthys polylepis).

Meanwhile, Yunita (2012) found 13 families of 26 species. Family Belontiidae and family Cyprinidae each had 5 species. While family Bagridae and family Channidae had 3 species and family Claridae 2 species. The Anabantidae, Helostomatidae, Mastacembelidae, Osphronemidae, Pristolepididae, Siluridae, Synbranchidae, Tetraodontidae families each had 1 species. The largest number of individuals was the Belontiidae family with the highest number amounting to 5,213 individuals, the Helostomatidae family with 2,426 individuals, the Anabantidae family with 2,355 individuals, the Cyprinidae family with 2,347 individuals and the Bagridae family with 2,061 individuals.

The following are the results of sampling tests conducted on 29 July 2020, 10 August 2020 and 19 August 2020:

Table 1 - Lead Content Analysis Result in Fish (Sampling on 29 July 2020)

\begin{tabular}{|c|c|c|c|c|c|c|}
\hline No & Fish Type & Location & $\begin{array}{l}\text { Test Result } \\
(\mathrm{mg} / \mathrm{kg})\end{array}$ & $\begin{array}{c}\text { Indonesian National } \\
\text { Standard (SNI) } \\
(\mathrm{mg} / \mathrm{kg})\end{array}$ & $\begin{array}{c}\text { EU } \\
\text { Standard } \\
(\mathrm{mg} / \mathrm{kg})\end{array}$ & Conclusion \\
\hline 1 & $\begin{array}{c}\text { Gabus } \\
\text { (Channa striata) }\end{array}$ & Middle & 0.980 & $\begin{array}{l}0.3 \\
0.3\end{array}$ & 0.3 & $\begin{array}{c}\text { Fulfilling the quality } \\
\text { standards for SNI and EU }\end{array}$ \\
\hline 2 & $\begin{array}{c}\text { Gabus } \\
\text { (Channa striata) }\end{array}$ & Outlet & 1.026 & $\begin{array}{l}0.3 \\
0.3 \\
\end{array}$ & 0.3 & $\begin{array}{l}\text { Not fulfilling thet quality } \\
\text { standards for SNI and EU }\end{array}$ \\
\hline 3 & $\begin{array}{c}\text { Toman } \\
\text { (Channa } \\
\text { micropeltes) }\end{array}$ & Middle & 0.508 & $\begin{array}{l}0.3 \\
0.3\end{array}$ & 0.3 & $\begin{array}{l}\text { Not fulfilling thet quality } \\
\text { standards for SNI and EU }\end{array}$ \\
\hline 4 & $\begin{array}{l}\text { Toman } \\
\text { (Channa } \\
\text { micropeltes) }\end{array}$ & Outlet & 0.205 & $\begin{array}{l}0.3 \\
0.3\end{array}$ & 0.3 & $\begin{array}{l}\text { Fulfilling the quality } \\
\text { standards for SNI and EU }\end{array}$ \\
\hline 5 & $\begin{array}{c}\text { Boggy } \\
\text { (Trichopodus } \\
\text { trichopterus) }\end{array}$ & Middle & $<0.001$ & $\begin{array}{l}0.3 \\
0.3\end{array}$ & 0.3 & $\begin{array}{l}\text { Fulfilling the quality } \\
\text { standards for SNI and EU }\end{array}$ \\
\hline 6 & $\begin{array}{c}\text { Boggy } \\
\text { (Trichopodus } \\
\text { trichopterus) }\end{array}$ & Outlet & 0.372 & $\begin{array}{l}0.3 \\
0.3\end{array}$ & 0.3 & $\begin{array}{l}\text { Not fulfilling thet quality } \\
\text { standards for SNI and EU }\end{array}$ \\
\hline 7 & $\begin{array}{l}\text { Sepat Siam } \\
\text { (Trichogaster } \\
\text { pectoralis) }\end{array}$ & Moderate & 1.111 & $\begin{array}{l}0.3 \\
0.3\end{array}$ & 0.3 & $\begin{array}{l}\text { Does not meet quality } \\
\text { standards for SNI and EU }\end{array}$ \\
\hline 8 & $\begin{array}{l}\text { Sepat Siam } \\
\text { (Trichogaster } \\
\text { pectoralis) }\end{array}$ & Outlet & 0.691 & $\begin{array}{l}0.3 \\
0.3\end{array}$ & 0.3 & $\begin{array}{l}\text { Not fulfilling thet quality } \\
\text { standards for SNI and EU }\end{array}$ \\
\hline 9 & $\begin{array}{c}\text { Biawan } \\
\text { (Helostoma } \\
\text { temminckii) }\end{array}$ & Middle & 0.094 & $\begin{array}{l}0.3 \\
0.3\end{array}$ & 0.3 & $\begin{array}{l}\text { Fulfilling the quality } \\
\text { standards for SNI and EU }\end{array}$ \\
\hline 10 & $\begin{array}{c}\text { Biawan } \\
\text { (Helostoma } \\
\text { temminckii) } \\
\end{array}$ & Outlet & 0.799 & $\begin{array}{l}0.3 \\
0.3\end{array}$ & 0.3 & $\begin{array}{l}\text { Not fulfilling thet quality } \\
\text { standards for SNI and EU }\end{array}$ \\
\hline 11 & $\begin{array}{l}\text { Papuyu } \\
\text { (Anabas } \\
\text { testudineus) }\end{array}$ & Middle & 1.341 & $\begin{array}{l}0.3 \\
0.3\end{array}$ & 0.3 & $\begin{array}{l}\text { Not fulfilling thet quality } \\
\text { standards for SNI and EU }\end{array}$ \\
\hline
\end{tabular}

Note: SNI for fresh fish number 2729 of 2013; EU Standard based on D.Pisanello, Chemistry of Foods: EU Legal and Regulatory Approaches, 2014; * for predator fish.

The results of the lead content analysis in the waters of Lake Bangkau showed that $77 \%$ of fish samples from various types and locations did not meet the quality standards of SNI for Fresh Fish and European Union Standards. For the SNI, it is only fulfilled by $7 \%$, but for the European Union standard, it was not. Meanwhile, $16 \%$ of them met SNI and European Union Standards. This showed the unsafe consumption of fish in the waters of Lake Bangkau. Food Safety is a condition and effort to prevent food from being contaminated by biological, chemical and other objects that can disturb, harm and endanger human health and did not conflict with the religion, belief and culture of the community so that it is safe for consumption. Law No. 18 of 2012 concerning Food (Chapter I, Article 1, Paragraph 5). 
Table 2 - Lead Content Analysis Result in Fish (Sampin on 10 August 2020)

\begin{tabular}{|c|c|c|c|c|c|c|}
\hline No & Fish Type & Location & $\begin{array}{l}\text { Test Result } \\
(\mathrm{mg} / \mathrm{kg})\end{array}$ & $\begin{array}{c}\text { Indonesian National } \\
\text { Standard (SNI) } \\
(\mathrm{mg} / \mathrm{kg})\end{array}$ & $\begin{array}{c}\text { EU } \\
\text { Standard } \\
(\mathrm{mg} / \mathrm{kg})\end{array}$ & Conclusion \\
\hline 1 & $\begin{array}{c}\text { Gabus } \\
\text { (Channa striata) }\end{array}$ & Middle & 0.212 & $\begin{array}{l}0.3 \\
0.3 \\
\end{array}$ & 0.3 & $\begin{array}{l}\text { Fulfilling the quality standards } \\
\text { for SNI and EU }\end{array}$ \\
\hline 2 & $\begin{array}{c}\text { Gabus } \\
\text { (Channa striata) }\end{array}$ & Outlet & 0.631 & $\begin{array}{l}0.3 \\
0.3\end{array}$ & 0.3 & $\begin{array}{l}\text { Not fulfilling thet quality } \\
\text { standards for SNI and EU }\end{array}$ \\
\hline 3 & $\begin{array}{c}\text { Toman } \\
\text { (Channa } \\
\text { micropeltes) }\end{array}$ & Middle & 0.302 & $\begin{array}{l}0.3 \\
0.3\end{array}$ & 0.3 & $\begin{array}{l}\text { Fulfilling the quality standards } \\
\text { for SNI and EU }\end{array}$ \\
\hline 4 & $\begin{array}{l}\text { Toman } \\
\text { (Channa } \\
\text { micropeltes) }\end{array}$ & Outlet & 0.361 & $\begin{array}{l}0.3 \\
0.3\end{array}$ & 0.3 & $\begin{array}{l}\text { Fulfilling the quality standards } \\
\text { for SNI and EU }\end{array}$ \\
\hline 5 & $\begin{array}{l}\text { Sepat Siam } \\
\text { (Trichogaster } \\
\text { pectoralis) }\end{array}$ & Middle & 0.341 & $\begin{array}{l}0.3 \\
0.3\end{array}$ & 0.3 & $\begin{array}{l}\text { Not fulfilling thet quality } \\
\text { standards for SNI and EU }\end{array}$ \\
\hline 6 & $\begin{array}{l}\text { Sepat Siam } \\
\text { (Trichogaster } \\
\text { pectoralis) }\end{array}$ & Outlet & 0.228 & $\begin{array}{l}0.3 \\
0.3\end{array}$ & 0.3 & $\begin{array}{l}\text { Fulfilling the quality standards } \\
\text { for SNI and EU }\end{array}$ \\
\hline 7 & $\begin{array}{l}\text { Biawan } \\
\text { (Helostoma } \\
\text { temminckii) }\end{array}$ & Middle & 0.940 & $\begin{array}{l}0.3 \\
0.3\end{array}$ & 0.3 & $\begin{array}{l}\text { Not fulfilling thet quality } \\
\text { standards for SNI and EU }\end{array}$ \\
\hline 8 & $\begin{array}{l}\text { Biawan } \\
\text { (Helostoma } \\
\text { temminckii) }\end{array}$ & Outlet & 0.715 & $\begin{array}{l}0.3 \\
0.3\end{array}$ & 0.3 & $\begin{array}{l}\text { Not fulfilling thet quality } \\
\text { standards for SNI and EU }\end{array}$ \\
\hline 9 & $\begin{array}{l}\text { Papuyu } \\
\text { Anabas } \\
\text { testudineus }\end{array}$ & Middle & 0.327 & $\begin{array}{l}0.3 \\
0.3\end{array}$ & 0.3 & $\begin{array}{l}\text { Not fulfilling thet quality } \\
\text { standards for SNI and EU }\end{array}$ \\
\hline 10 & $\begin{array}{c}\text { Papuyu } \\
\text { Anabas } \\
\text { testudineus }\end{array}$ & Outlet & 0.392 & $\begin{array}{l}0.3 \\
0.3\end{array}$ & 0.3 & $\begin{array}{l}\text { Not fulfilling thet quality } \\
\text { standards for SNI and EU }\end{array}$ \\
\hline
\end{tabular}

Note: SNI for fresh fish number 2729 of 2013; EU Standard based on D.Pisanello, Chemistry of Foods: EU Legal and Regulatory Approaches, 2014; * for predator fish.

Table 3 - Lead Content Analysis Result in Fish (Sampling 19 August 2020)

\begin{tabular}{|c|c|c|c|c|c|c|}
\hline No & Fish Type & Location & $\begin{array}{l}\text { Test Result } \\
(\mathrm{mg} / \mathrm{kg})\end{array}$ & $\begin{array}{c}\text { Indonesian National } \\
\text { Standard (SNI) } \\
(\mathrm{mg} / \mathrm{kg})\end{array}$ & $\begin{array}{c}\text { EU } \\
\text { Standard } \\
(\mathrm{mg} / \mathrm{kg})\end{array}$ & Conclusion \\
\hline 1 & $\begin{array}{c}\text { Gabus } \\
\text { (Channa striata) }\end{array}$ & Middle & 1.024 & $\begin{array}{l}0.3 \\
0.3\end{array}$ & 0.3 & $\begin{array}{l}\text { Not fulfilling thet quality } \\
\text { standards for SNI and EU }\end{array}$ \\
\hline 2 & $\begin{array}{c}\text { Gabus } \\
\text { (Channa striata) }\end{array}$ & Outlet & 0.459 & $\begin{array}{l}0.3 \\
0.3 \\
\end{array}$ & 0.3 & $\begin{array}{l}\text { Not fulfilling thet quality } \\
\text { standards for SNI and EU }\end{array}$ \\
\hline 3 & $\begin{array}{c}\text { Boggy } \\
\text { (Trichopodus } \\
\text { trichopterus) } \\
\end{array}$ & Middle & 1.037 & $\begin{array}{l}0.3 \\
0.3\end{array}$ & 0.3 & $\begin{array}{l}\text { Not fulfilling thet quality } \\
\text { standards for SNI and EU }\end{array}$ \\
\hline 4 & $\begin{array}{c}\text { Boggy } \\
\text { (Trichopodus } \\
\text { trichopterus) }\end{array}$ & Outlet & 0.837 & $\begin{array}{l}0.3 \\
0.3\end{array}$ & 0.3 & $\begin{array}{l}\text { Not fulfilling thet quality } \\
\text { standards for SNI and EU }\end{array}$ \\
\hline 5 & $\begin{array}{l}\text { Sepat Siam } \\
\text { (Trichogaster } \\
\text { pectoralis) }\end{array}$ & Middle & 0.636 & $\begin{array}{l}0.3 \\
0.3\end{array}$ & 0.3 & $\begin{array}{l}\text { Not fulfilling thet quality } \\
\text { standards for SNI and EU }\end{array}$ \\
\hline 6 & $\begin{array}{l}\text { Sepat Siam } \\
\text { (Trichogaster } \\
\text { pectoralis) }\end{array}$ & Outlet & 0.444 & $\begin{array}{l}0.3 \\
0.3\end{array}$ & 0.3 & $\begin{array}{l}\text { Not fulfilling thet quality } \\
\text { standards for SNI and EU }\end{array}$ \\
\hline 7 & $\begin{array}{l}\text { Biawan } \\
\text { (Helostoma } \\
\text { temminckii) }\end{array}$ & Middle & 0.602 & $\begin{array}{l}0.3 \\
0.3\end{array}$ & 0.3 & $\begin{array}{l}\text { Not fulfilling thet quality } \\
\text { standards for SNI and EU }\end{array}$ \\
\hline 8 & $\begin{array}{c}\text { Biawan } \\
\text { (Helostoma } \\
\text { temminckii) }\end{array}$ & Outlet & 0.525 & $\begin{array}{l}0.3 \\
0.3\end{array}$ & 0.3 & $\begin{array}{l}\text { Not meeting the quality } \\
\text { standards for SNI and EU }\end{array}$ \\
\hline 9 & $\begin{array}{c}\text { Papuyu } \\
\text { Anabas testudineus }\end{array}$ & Middle & 1.024 & $\begin{array}{l}0.3 \\
0.3\end{array}$ & 0.3 & $\begin{array}{l}\text { Not meeting the quality } \\
\text { standards for SNI and EU }\end{array}$ \\
\hline 10 & $\begin{array}{c}\text { Papuyu } \\
\text { Anabas testudineus }\end{array}$ & Outlet & 0.459 & $\begin{array}{l}0.3 \\
0.3\end{array}$ & 0.3 & $\begin{array}{l}\text { Not meeting the quality } \\
\text { standards for SNI and EU }\end{array}$ \\
\hline
\end{tabular}

Note: SNI for fresh fish number 2729 of 2013; EU Standard based on DPisanello, Chemistry of Foods: EU Legal and Regulatory Approaches, 2014; * for predator fish. 


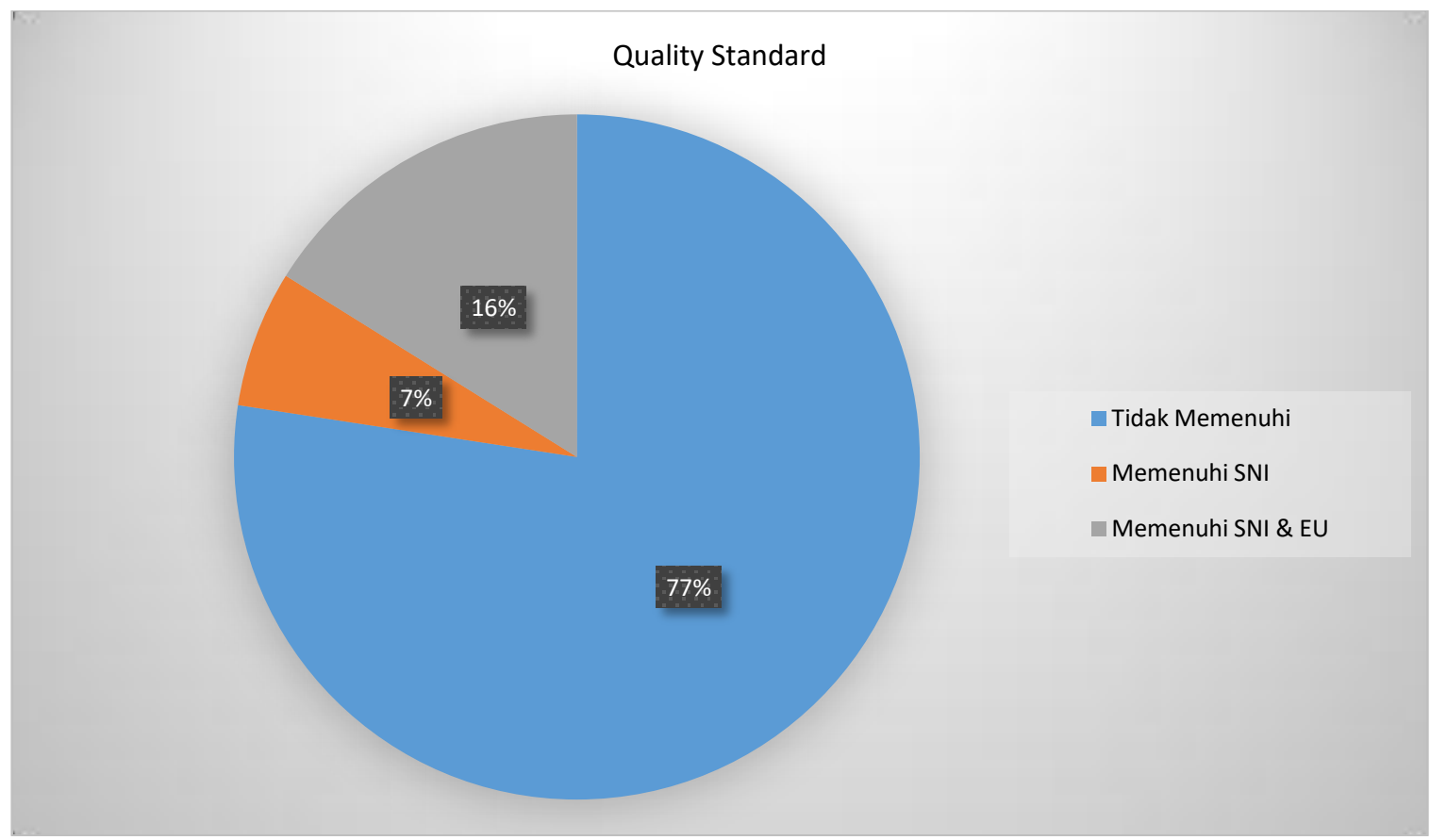

Figure 3 - Percentage of Fish Samples that Fulfill Quality Standards

Lead toxicity, also knon as lead poisoning, can be acute or chronic. Acute can cause loss of appetite, headaches, hypertension, abdominal pain, impaired kidney function, fatigue, wakeful, arthritis, hallucinations and vertigo. It generally occurs in the workplace and in some manufacturing industries that use lead. Chronic lead exposure can produce mental retardation, congenital disabilities, psychosis, autism, allergies, dyslexia, weight loss, hyperactivity, paralysis, muscle weakness, brain damage, kidney damage and even death (Martin \& Griswold, 2009); (Taylor et al., 2012). Even though lead poisoning is preventable, it is still a dangerous disease that can affect most organs of the body. The plasma membrane moves into the brain when areas of the brain are exposed to increased levels of lead concentration, resulting in a condition called edema (Brochin et al., 2008).

\section{CONCLUSION}

The results of the study indicate that $77 \%$ of fish samples from various types and locations do not meet the SNI (Indonesian National Standard) quality standards for fresh fish and the European Union (EU) standards related to lead content. For the SNI, it is only fulfilled by $7 \%$, but for the European Union standard, it is not. Meanwhile, $16 \%$ of them meet SNI and European Union Standards. This shows the unsafe consumption of fish in the waters of Bangkau Lake, especially the heavy metal content of lead. It is necessary to take comprehensive and integrated steps from various sectors and all communities around Bangkau Lake to reduce the lead content in the waters.

\section{REFERENCES}

1. Asyari.A.D.Utomo and S.Nurdawati.2002.Inventarisasi and biologi reproduksi beberapa jenis ikan pada berbagai tipe suaka perikanan di Sungai Lempuing Kab.Ogan Komering Ilir, Sumatera Selatan.Jurnal Ilmu-Ilmu Perairan and Perikanan Indonesia, 9(1).

2. Asyari.2006. Characteristics of Habitat and Fish Species on Some Fishery Reserve Areas at Barito Rivers Basin, South Kalimantan.Jurnal IImu-ilmu Perairan and Perikanan Indonesia, Jilid 13, Nomor 2:155-163.

3. Brochin R, Leone S, Phillips D, Shepard N, Zisa D, Angerio A.(2008). The cellular effect of lead poisoning and its clinical picture.GUJHS.5(2):1-8.

4. Chairuddin G, Rahman M, Masyhuri A, Husin S.1999.Usaha budidaya mina unggas itik 
ala-bio dengan ikan betutu (Oxeleotris marmorata).Laporan penelitian.134 hal.

5. Connel, D.W. and GJ.Miller.2006.Kimia and Ekotoksikologi Pencemaran.Y.Koestoer (Penerjemah).Universitas Indonesia Press.Jakarta.

6. Darmono.2001.Lingkungan Hidup and Pencemaran Hubungannya dengan Toksikologi Senyawa Logam. Universitas Indonesia Press.Jakarta.

7. Dahuri, R,.2004.Wujud Nyata Kebijakan Pemerintah dalam Pengelolaan Perikanan yang Bertanggung Jawab.Disampaikan dalam Semiloka Paradigma Baru Pengelolaan Perikanan yang Bertanggung Jawab dalam Rangka Mewujudkan Kelestarian Sumberdaya and Manfaat Ekonomi Maksimal.Jakarta, Hotel Aryaduta.

8. Effendi, H.2003.Telaah Kualitas Air Bagi Pengelolaan Sumber Daya and Lingkungan Perairan.Penerbit Kanisius.Yogyakarta.

9. Ivanciuc, T., Ivanciuc, O., and Klein, D.J.2006.Modelling the Bioconcentration Factor and Biaccumulation Factor of Polychlorinated Biphenyls with Posetic Quantitative Super Structure/Activity Relationship (QSSAR).Molecular Diversity, 10:133-145.

10. Khiatuddin, M.2003.Melestarikan Sumberdaya Air dengan Teknologi Rawa Buatan.Gadjah Mada University Press.

11. Martin S, Griswold W.(2009).Human health eff ects of heavy metals.Environmental Science and Technology Briefs for Citizens (15):1-6.

12. Riyadi, PH, Bambang, AN., and Agustini, TW.2007.Analisis Kebijakan Keamanan Pangan Produk Hasil Perikanan di Pantai Utara Jawa Tengan and Daerah Istimewa Yogyakarta.Jurnal Pasir Laut, 2 (2):30-39.

13. Taylor MP, Winder C, Lanphear BP. (2012).Eliminating childhood lead toxicity in Australia: a call to lower the intervention level.MJA 197(9):493.

14. Undang-Undang No.8 Tahun 1999 tentang Perlindungan Konsumen.

15. Undang No 18 Tahun 2012 Tentang Pangan.

16. Yunita, R.2012.Karakteristik Perairan Rawa Bangkau and Keanekaragaman Ikan Kabupaten Hulu Sungai Selatan Propinsi Kalimantan Selatan. 